Research Report No. 1/2007

\title{
What are Aboriginal Rights?
}

Brian Slattery

Osgoode Hall Law School of York University, slattery@yorku.ca

Follow this and additional works at: http:/ / digitalcommons.osgoode.yorku.ca/clpe

\section{Recommended Citation}

Slattery, Brian, "What are Aboriginal Rights?" (2007). Comparative Research in Law \& Political Economy. Research Paper No. $1 / 2007$. http://digitalcommons.osgoode.yorku.ca/clpe/218

This Article is brought to you for free and open access by the Research Papers, Working Papers, Conference Papers at Osgoode Digital Commons. It has been accepted for inclusion in Comparative Research in Law \& Political Economy by an authorized administrator of Osgoode Digital Commons. 


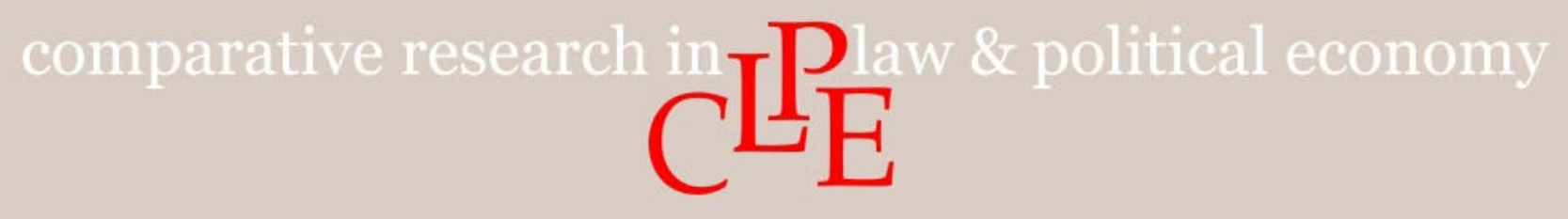

\section{Law Research Institute Research Paper Series}

CLPE Research Paper 1/2007

Vol. 03 No. 02 (2007)

Brian Slattery

\section{What Are Aboriginal Rights?}

Keywords: aboriginal rights, custom, title, Constitution Act, treaty rights

JEL Classification: K19, K34

Author Contact:

Osgoode Hall Law School, York University

4700 Keele St., Toronto, ON, Canada M3J 1P3

Email: bslattery@osgoode.yorku.ca

Forthcoming in Foster, Raven \& Webber, eds. Let Right Be Done: Calder, Aboriginal Title, and the Future of Indigenous Rights (Vancouver: University of British Columbia Press, 2007)

This paper can be downloaded without charge from the Social Science Research Network Electronic Library at: http://ssrn.com/abstractid= 967493

An index to the working papers in the Comparative Research in Law and Political Economy Research Paper Series is located at: http://www.comparativeresearch.net

CLPE RPS Editors: John Cioffi (University of California at Riverside), Peer Zumbansen (Osgoode Hall Law School, Toronto, Director, Comparative Research in Law and Political Economyl

Production Editor: James Brink (Osgoode Hall Law School, Toronto) 



\section{CLPE Research Paper 1/2007 \\ Vol. 03 No. 02 (2007)}

\section{Brian Slattery}

\section{What Are Aboriginal Rights?}

Aboriginal rights in Canada are often viewed as specific rights-rights that are grounded in the specific practices and customs of particular aboriginal peoples and that differ from people to people. This article argues that these specific rights are in fact concrete instantiations of a panoply of generic aboriginal rights that are presumptively held by all aboriginal groups under Canadian common law. They include the right to conclude treaties, the right to customary law, the right to honourable treatment by the Crown, the right to an ancestral territory, the right of cultural integrity, and the right of selfgovernment. These basic rights have a uniform character, which does not change from group to group. Specific rights, by contrast, arise under the auspices of generic rights and assume different forms in different aboriginal groups, depending on the particular circumstances of each group. Ranged between generic rights and specific rights are rights of intermediate generality, which relate to particular subjectmatters such as sustenance, spirituality and language. The article suggests that this scheme provides a simple and practical way of understanding the otherwise bewildering array of aboriginal rights recognized in section 35(1) of the Constitution Act, 1982.

Keywords: aboriginal rights, custom, title, Constitution Act, treaty rights

JEL Classification: K19, K34

Author Contact: Brian Slattery

Osgoode Hall Law School, York University

4700 Keele St., Toronto, ON, Canada M3J 1P3

Email: bslattery@osgoode.yorku.ca 


\section{What Are Aboriginal Rights?}

\section{Brian Slattery $^{1}$}

This paper will appear in Foster, Raven $\oplus$ Webber, eds. Let Right Be Done: Calder, Aboriginal Title, and the Future of Indigenous Rights (Vancouver: University of British Columbia Press, forthcoming in 2007). The paper is still subject to editing, so if you would like to quote from it, please contact me first at slattery@yorku.ca.

\section{INTRODUCTION}

Section 35(1) of the Constitution Act, 1982 recognizes and affirms the "existing aboriginal and treaty rights of the aboriginal peoples of Canada" ${ }^{2}$ The provision clearly builds on the Supreme Court's recognition of aboriginal rights in the landmark Calder ${ }^{3}$ case, decided a decade earlier. However the sparse wording leaves open a number of fundamental questions. What precisely are aboriginal rights and where do they come from? Are they based on indigenous customary law, or the common law, or perhaps international law, or even natural law? Do all aboriginal peoples have the same set of aboriginal rights or does each group have its own specific set?

${ }^{1}$ Osgoode Hall Law School, York University, Toronto. The author is grateful to Professors Kent McNeil and Jeremy Webber for their helpful comments on an earlier draft of this paper.

${ }^{2}$ Constitution Act, 1982, being Schedule B to the Canada Act 1982 (U.K.), 1982, c. 11.

${ }^{3}$ Calder v. Attorney General of British Columbia (1973), 34 D.L.R.(3d.) 145 (S.C.C.). 
These are difficult questions, which do not allow for simple or pat answers. Since 1982, many important pieces of the puzzle have been furnished by the Supreme Court of Canada in a series of significant decisions. However the pieces still lie scattered about in a somewhat disconnected fashion. This paper attempts to fit them together and fill in the gaps, so as to provide a coherent vision of aboriginal rights in Canada. The paper deals first with the important distinction between specific and generic rights, which emerges from the Court's judgments in the Van der Peet ${ }^{4}$ and Delgamuukw ${ }^{5}$ cases. It then discusses the main types of generic rights and their relationship to specific rights, arguing that generic rights provide the foundation for specific rights and supply the criteria that govern them. Generic rights are not only uniform in character, but also universal in distribution: they comprise a set of fundamental rights held by all aboriginal groups in Canada.

\section{SPECIFIC AND GENERIC RIGHTS ${ }^{6}$}

In the Van der Peet case, ${ }^{7}$ the Supreme Court recognized a class of aboriginal rights whose nature and scope are determined by the particular circumstances of each specific aboriginal group. The Court held that in order to constitute an aboriginal right protected by s. 35(1) of the Constitution Act, 1982, a present-day activity of an aboriginal group must be based on a practice,

${ }^{4}$ R. v. Van der Peet [1996] 2 S.C.R. 507 (S.C.C.).

${ }^{5}$ Delgamuukw v. British Columbia [1997] 3 S.C.R. 1010 (S.C.C.).

${ }^{6}$ This section draws on Brian Slattery, "Making Sense of Aboriginal and Treaty Rights" (2000) 79 Can. Bar Rev. 196 at 211-13.

${ }^{7}$ R. v. Van der Peet [1996] 2 S.C.R. 507 (S.C.C.). See also the summary of the test in Mitchell v. M.N.R. [2001] 1 S.C.R. 911 (S.C.C.) at paras. 12-13. 
custom or tradition that was integral to the distinctive culture of that specific group in the period prior to European contact. ${ }^{8}$ To qualify as "integral" to a particular culture, a practice has to be a central and significant part of the culture, one of the things that makes the society what it is. So, aspects of an aboriginal society that are only incidental or occasional do not qualify; they must be defining and central features of the society.' A practice has to be a characteristic element of the culture; however, it does not need to be unique or different from the practices of other societies. So, for example, fishing for food may constitute an aboriginal right, even though it is practised by many different societies around the world. ${ }^{10}$

The rights recognized in Van der Peet are what we may call specific rights-rights whose existence, nature and scope are determined by factors that are particular to each aboriginal group. Specific rights differ from group to group and sometimes take quite specialized forms. For example, in the Gladstone

${ }^{8}$ R. v. Van der Peet [1996] 2 S.C.R. 507 (S.C.C.) at paras. 46, 60.

${ }^{9}$ Ibid. at paras. 55-56. In R. v. Sappier; R. v. Gray, 2006 SCC 54 (S.C.C.), the Supreme Court stressed that this criterion should be applied flexibly "because the object is to provide cultural security and continuity for the particular aboriginal society" (para. 33). It does not mean that the pre-contact practice has to go to the "core of the society's identity", in the sense of constituting its single most important defining character (para. 40). Nor should the notion that the practice must be a "defining feature" of the aboriginal society be used "to create artificial barriers to the recognition and affirmation of aboriginal rights" (para. 41). The purpose is "to understand the way of life of the particular aboriginal society, pre-contact, and to determine how the claimed right relates to it" (para. 40).

${ }^{10}$ R. v. Van der Peet [1996] 2 S.C.R. 507 (S.C.C.) at paras. 71-72. The point is reiterated and sharpened in R. v. Sappier; R. v. Gray, 2006 SCC 54 (S.C.C.) at paras. 42-46. 
case $^{11}$ the Supreme Court held that the members of the Heiltsuk people of British Columbia had an aboriginal right to trade in herring spawn on kelp (a kind of seaweed) and that this trade might be conducted on a commercial basis. The Court's holding was based on historical and anthropological evidence showing that the Heiltsuk had engaged in such a trade as an integral part of their culture prior to contact with Europeans. The right was obviously one that few other aboriginal groups would be able to claim. It was rooted in the distinctive practices of the Heiltsuk Nation, and indeed was confined to trade in a single, rather exotic commodity.

In Van der Peet, the Supreme Court expressed the view that all aboriginal rights were specific rights. ${ }^{12}$ However, this proved to be a premature generalization. It was quietly discarded by the Court in the Delgamuukw case, ${ }^{13}$ decided the following year. The hereditary chiefs of the Gitksan and Wet'suwet'en peoples asserted aboriginal title to a large tract of land in northern British Columbia, a claim that was contested by the British

${ }^{11}$ R. v. Gladstone [1996] 2 S.C.R. 723 (S.C.C.).

${ }^{12}$ R. v. Van der Peet [1996] 2 S.C.R. 507 (S.C.C.) at para. 69.

${ }^{13}$ Delgamuukw v. British Columbia [1997] 3 S.C.R. 1010 (S.C.C.). For discussion, see Owen Lippert, ed. Beyond the Nass Valley: National Implications of the Supreme Court's Delgamuukw Decision (Vancouver: The Fraser Institute, 2000); Kent McNeil, Emerging Justice? Essays on Indigenous Rights in Canada and Australia (Saskatoon: University of Saskatchewan Native Law Centre, 2001) at 58-160. The concept of aboriginal title is analysed in Brian Slattery, "Understanding Aboriginal Rights" (1987) 66 Can. Bar Rev. 727; Kent McNeil, Common Law Aboriginal Title (Oxford: Clarendon Press, 1989); Patrick Macklem, "What's Law Got to Do With It? The Protection of Aboriginal Title in Canada" (1997) 35 Osgoode Hall L.J. 125; Kent McNeil, "Aboriginal Title and the Supreme Court: What's Happening?" (2006) 69 Sask. L. Rev. (forthcoming); Brian Slattery, "The Metamorphosis of Aboriginal Title" (2006) 85 Can. Bar Rev. (forthcoming). 
Columbia government. In argument before the Court, the parties to the case advanced strikingly different conceptions of aboriginal title, which effectively raised the issue whether aboriginal title was a specific right, grounded in factors particular to each aboriginal group, or a right of a more generalized nature.

The aboriginal claimants maintained that aboriginal title was equivalent to an inalienable fee simple, arguing that it was a right of a fixed and uniform character, similar in this respect to standard estates known to the English law of real property. According to this view, the nature of aboriginal title did not vary from group to group, depending on their particular culture or customs, but was the same in all cases. As such, aboriginal title did not constitute a specific right but was a right of a standardized character.

In reply, the governments of British Columbia and Canada maintained that aboriginal title to land was simply a collection of particular aboriginal rights to engage in specific culture-based activities on the land. In other words, aboriginal title had no definite character; it was just a bundle of specific aboriginal rights, each of which had to be proven independently. At best, aboriginal title gave a group the right to the exclusive use and occupation of the land in order to exercise these specific rights. The group would not be entitled to use the land for any purposes it wanted; it would be limited to exercising the rights in its particular bundle. In effect, in order to engage in a certain activity on the land, a claimant group would have to prove that the particular activity in question satisfied the Van der Peet test-that it was an element of a practice, custom or tradition 
that was integral to the group's distinctive society at the time of European contact. ${ }^{14}$

So, according to the governmental argument, the content of aboriginal title was variable. It differed from group to group, depending on the group's particular cultural practices at the time of European contact. By contrast, according to the aboriginal parties, the content of aboriginal title was uniform and did not depend on the group's historical practices. If a group had aboriginal title, it could use the land in any way it wanted, subject only to a restriction on transfers to third parties.

In its judgment, the Supreme Court rejected the governmental argument and adopted a position close to that of the aboriginal parties. Chief Justice Lamer stated that aboriginal title is governed by two principles. ${ }^{15}$ Under the first principle, a group holding aboriginal title has the right to the exclusive use and occupation of the land for a broad range of purposes. These purposes do not need to be grounded in the group's ancestral practices, customs and traditions. So, a group that originally lived mainly by hunting, fishing and gathering would be free to farm the land, raise cattle on it, exploit its natural resources or use it for residential, commercial or industrial purposes. Nevertheless, according to the second principle, land held under aboriginal title is subject to an "inherent limit". This prevents the land from being used in a manner that is irreconcilable with the fundamental nature of the group's attachment to the land, so as to ensure that the land is preserved for use by future generations. In other words, the group may not ruin the land or render it unusable for its original purposes.

\footnotetext{
${ }^{14}$ Delgamuukw v. British Columbia [1997] 3 S.C.R. 1010 (S.C.C.) at paras. 110-11.

${ }^{15}$ Ibid. at paras. 116-32.
} 
The crucial point to note here is that the Supreme Court treats aboriginal title as a uniform right, whose basic dimensions do not vary from group to group according to their traditional ways of life. All groups holding aboriginal title have fundamentally the same kind of right, subject only to minor variations stemming from the inherent limit. In effect, the Supreme Court recognizes that aboriginal title is not a specific right of the kind envisaged in Van der Peet, or even a bundle of specific rights. Aboriginal title is what we may call a generic right-a right of a standardized character that is basically identical in all aboriginal groups where it occurs. The fundamental dimensions of the right are determined by the common law doctrine of aboriginal rights rather than by the unique circumstances of each group.

In short, in Van der Peet and Delgamuukw the Supreme Court recognizes two different kinds of aboriginal rights-specific rights and generic rights. Specific rights are rights whose nature and scope are defined by factors pertaining to a particular aboriginal group. As such, they vary in character from group to group. Of course, different aboriginal groups may have similar specific rights, but this is just happenstance; it does not flow from the nature of the right. By contrast, generic rights are rights of a uniform character whose basic contours are established by the common law of aboriginal rights. All aboriginal groups holding a certain generic right have basically the same kind of right. The essential nature of the right does not vary according to factors peculiar to the group.

The distinction between specific and generic rights gives rise to a number of important questions. First, is aboriginal title the sole instance of a generic right, or are there others? Second, what is the precise relationship between generic and specific rights; are they completely distinct or do they overlap in some fashion? Third, are generic rights not only uniform in character but also universal in distribution; that is, are they held by all aboriginal groups, or only by certain groups and not others? Fourth, are generic and specific rights both grounded in 
historical practice; if so, are they open to evolution and change? The remainder of this paper will be devoted to answering these questions.

\section{THE RANGE AND CHARACTER OF GENERIC RIGHTS}

Is aboriginal title the only example of a generic right? If we review the Van der Peet decision in the light of Delgamuukw, we come to a surprising conclusion. Recall that in Van der Peet the Court holds that aboriginal groups have the right to engage in activities based on the practices, customs and traditions that were integral to their distinctive cultures at the time of European contact. To be "integral" to a particular culture, a practice must be a central and significant part of the culture, one of the things that makes the society what it is. ${ }^{16}$ When we stand back from this decision, we can see that it has the effect of recognizing another generic right: it holds that aboriginal peoples have the generic right to maintain the central and significant features of their historical cultures.

At the abstract level, this right has a fixed and uniform character. Each and every aboriginal group has the same general right-to maintain the principal aspects of their culture. Of course, what is "central and significant" varies from group to group, in accordance with their particular circumstances, so that at the concrete level the abstract right blossoms into a variety of distinctive specific rights-a matter we will come back to later. However, the point to grasp here is that the abstract right itself is uniform. As such, it constitutes a generic right-what we may call the right of cultural integrity.

\footnotetext{
${ }^{16}$ R. v. Van der Peet [1996] 2 S.C.R. 507 (S.C.C.).
} 
Are there still other generic aboriginal rights? A little reflection shows that the answer is yes. Here is a tentative list of generic rights, which includes the two rights already identified:

- the right to conclude treaties

- the right to customary law

- the right to honourable treatment by the Crown

- the right to an ancestral territory (aboriginal title)

- the right of cultural integrity

- the right of self-government

This list is not necessarily complete, and some rights (such as the right of cultural integrity) may need to be sub-divided. However, it includes the most important generic rights tacitly recognized in Supreme Court cases so far. As the jurisprudence evolves, further generic rights may come to light. Here we will say a few words about each of the rights listed, enough to give a taste of the subject.

\section{A. THE RIGHT TO CONCLUDE TREATIES}

Aboriginal peoples have the right to conclude binding treaties with the Crown and to enforce the Crown's treaty promises in the courts. ${ }^{17}$ At Canadian common law, the treaty-making capacity of aboriginal groups has a fixed and uniform character which does not vary from group to group. The capacity of the Blackfoot is no greater or less than that of the Micmac or the Innu. All have the same power to negotiate treaties with the Crown, which are protected under s. 35(1) of the Constitution Act, 1982. As such, the right to conclude treaties constitutes a generic aboriginal right.

\footnotetext{
${ }^{17}$ The capacity of Indian nations to conclude treaties with the Crown is comprehensively reviewed in R. V. Sioui [1990] 1 S.C.R. 1025 (S.C.C.) at 103743.
} 
The right of aboriginal peoples to treat with the Crown is matched by the Crown's right to treat with aboriginal peoples under the royal prerogative. In both cases, the power flows from the inter-societal law of aboriginal rights, which forms part of the common law of Canada. ${ }^{18}$ Since the time of Confederation, the Crown's power in this area has vested primarily in the federal government under s. 91(24) of the Constitution Act, 1867.

The right to conclude treaties is one of the most important of the generic rights held by aboriginal peoples, with roots reaching back to the earliest days of European settlement on the continent. It is a highly distinctive right, without exact parallels in other spheres of Canadian constitutional law. Although provincial governments may of course conclude agreements with the federal government, these agreements have a quite different character and do not hold the constitutional status and protection enjoyed by aboriginal treaties. ${ }^{19}$

\footnotetext{
${ }^{18}$ For discussion of the inter-societal character of this law, see Brian Slattery, "Understanding Aboriginal Rights" (1987) 66 Can. Bar Rev. 727 at 736-41, 744-45; Brian Slattery, "Making Sense of Aboriginal and Treaty Rights" (2000) 79 Can. Bar Rev. 196 at 198-206; Brian Slattery, "The Metamorphosis of Aboriginal Title" (2006) 85 Can. Bar Rev. (forthcoming). For parallel approaches, see Mark D. Walters, "British Imperial Constitutional Law and Aboriginal Rights: A Comment on Delgamuukw v. British Columbia" (1992) 17 Queen's L.J. 350; Jeremy Webber, "Relations of Force and Relations of Justice: The Emergence of Normative Community between Colonists and Aboriginal Peoples" (1995) 33 Osgoode Hall L.J. 623; John Borrows, "With or Without You: First Nations Law (in Canada)" (1996) 41 McGill L.J. 629; John Borrows \& Leonard I. Rotman, "The Sui Generis Nature of Aboriginal Rights: Does It Make a Difference?" (1997) 36 Alta. L. Rev. 9; Mark D. Walters, "The "Golden Thread" of Continuity: Aboriginal Customs at Common Law and Under the Constitution Act, 1982" (1999) 44 McGill L.J. 711.

${ }^{19}$ On the constitutional effects of federal-provincial agreements, see Reference Re Canada Assistance Plan (B.C.) [1991] 2 S.C.R. 525, and
} 


\section{B. THE RIGHT TO CUSTOMARY LAW}

Aboriginal peoples have the right to maintain and develop their distinctive systems of customary law within an all-embracing federal framework that features multiple and overlapping legal systems and levels of government. ${ }^{20}$ The introduction of French and English laws into the colonies founded by the European powers did not have the effect of wiping out the customary laws of aboriginal groups, which continued to operate within their respective spheres. As Justice McLachlin observes in Van der Peet: ${ }^{21}$

The history of the interface of Europeans and the common law with aboriginal peoples is a long one. As might be expected of such a long history, the principles by which the interface has been governed have not always been consistently applied. Yet running through this history, from its earliest beginnings to the present time is a golden thread-the recognition by the common law of the ancestral laws and customs [of] the aboriginal peoples who occupied the land prior to European settlement.

discussion in Peter W. Hogg, Constitutional Law of Canada, 3rd ed. (Scarborough, Ont.: Carswell, 1992) at 12.3(a).

${ }^{20}$ See Connolly v. Woolrich (1867), 17 R.J.R.Q. 75 (Que. S.C.); Casimel v. Insurance Corp. of British Columbia [1994] 2 C.N.L.R. 22 (B.C.C.A.); R. v. Van der Peet [1996] 2 S.C.R. 507 (S.C.C.) esp. at paras. 38-40; Delgamuukw v. British Columbia [1997] 3 S.C.R. 1010 (S.C.C.) at paras. 146-48; Campbell v. British Columbia (Attorney General) [2000] 4 C.N.L.R. 1 (B.C.S.C.) at paras. 83-136; Mitchell v. M.N.R. [2001] 1 S.C.R. 911 (S.C.C.) at paras. 9-10, 61-64, 141-54.

${ }^{21}$ R. v. Van der Peet [1996] 2 S.C.R. 507 (S.C.C.) at para. 263. Justice McLachlin was dissenting, but not on this point. 
The right of aboriginal peoples to maintain their own laws is a generic right, whose basic scope is determined by the common law doctrine of aboriginal rights. It does not differ from group to group or from area to area. The Mohawk and Haida peoples are equally entitled to enjoy their respective systems of customary law. Nevertheless, the legal systems protected by the generic right obviously differ in content. Mohawk laws are not the same as Haida laws.

Aboriginal systems of customary law have a status similar to that of provincial legal systems. At Confederation, the Constitution Act, 1867 provided that the laws in force in the provinces would continue in force, subject to the legislative powers of the federal and provincial governments. ${ }^{22}$ Existing bodies of provincial law were carried forward into the new federation, and the power to amend or repeal those laws was distributed between the two main levels of government.

\section{THE Right TO HONOURABLE TREATMENT BY THE CROWN}

Aboriginal peoples have the right to the fiduciary protection of the Crown and the right to the performance of particular fiduciary duties flowing from that relationship. ${ }^{23}$ In the Sparrow case, ${ }^{24}$ the Supreme Court stated:

...the Government has the responsibility to act in a fiduciary capacity with respect to aboriginal peoples.

\footnotetext{
${ }^{22}$ Section 129, Constitution Act, 1867.

${ }^{23}$ See Guerin v. The Queen [1984] 2 S.C.R. 335 (S.C.C.); R. v. Sparrow [1990] 1 S.C.R. 1075 (S.C.C.); R. v. Van der Peet [1996] 2 S.C.R. 507 (S.C.C.) at paras. 24-25; Wewaykum Indian Band v. Canada [2002] S.C.R. (S.C.C.).

${ }^{24}$ R. v. Sparrow [1990] 1 S.C.R. 1075 (S.C.C.) at 1108.
} 
The relationship between the Government and aboriginals is trust-like, rather than adversarial, and contemporary recognition and affirmation of aboriginal rights must be defined in light of this historic relationship.

Although the Court was referring here to s. 35(1) of the Constitution Act, 1982, subsequent Supreme Court decisions have made it clear that the Crown's fiduciary responsibility is not confined to this context but accompanies and controls the discretionary powers that the Crown historically has assumed over the lives of aboriginal peoples. ${ }^{25}$ As McLachlin C.J. notes in the Mitchell case, ${ }^{26}$ from early days the Crown asserted sovereignty over aboriginal lands and underlying title to the soil: from this assertion "arose an obligation to treat aboriginal peoples fairly and honourably, and to protect them from exploitation".

At the most abstract level, the right to honourable treatment by the Crown is a generic right, which vests uniformly in aboriginal peoples across Canada. The point is underlined in the Haida Nation case ${ }^{27}$ where McLachlin C.J. holds that the honour of the Crown is always at stake in its dealings with aboriginal peoples. The Crown has the general duty to determine, recognize and respect the rights of aboriginal groups over which it has asserted sovereignty. This in turn binds the Crown to enter into treaty negotiations with aboriginal peoples for the purpose of reconciling their rights with the advent of Crown sovereignty and to achieve a just settlement. Pending the conclusion of

\footnotetext{
${ }^{25}$ Wewaykum Indian Band v. Canada [2002] S.C.R. (S.C.C.) at paras. 79-80.

${ }^{26}$ Mitchell v. M.N.R. [2001] 1 S.C.R. 911 (S.C.C.) at para. 9.

${ }^{27}$ Haida Nation v. British Columbia (Minister of Forests) [2004] 3 S.C.R. 511 (S.C.C.) at paras. 16-25.
} 
treaties determining these rights, the Crown has a duty to consult with aboriginal peoples whenever it undertakes actions that may affect their asserted rights, and also to accommodate these rights where necessary. In situations where the Crown has assumed discretionary control over specific aboriginal interests, the honour of the Crown gives rise to a fiduciary duty. This generally requires the Crown to act with reference to the aboriginal group's best interest in exercising its discretion over the specific aboriginal interest at stake.

In effect, then, the generic right to honourable treatment gives rise to a range of more precise rights and duties that attach to specific subject-matters in particular contexts. As Binnie J. explains in the Wewaykum case, ${ }^{28}$ not all obligations existing between the parties to a fiduciary relationship are themselves fiduciary in nature, and this observation holds true of the relationship between the Crown and aboriginal peoples. It is necessary to focus on the particular obligation or interest that is the subject matter of the dispute and to inquire whether the Crown had assumed sufficient discretionary control in relation thereto to ground a fiduciary obligation.

In the context of Indian reserves, for example, the nature and intensity of the Crown's fiduciary duties differ depending on whether the subject-matter relates to the creation of a new reserve or the protection of an existing reserve. ${ }^{29}$ Where the Crown sets out to create a new reserve in lands where the Indian beneficiaries have no prior treaty or aboriginal claims, its fiduciary duties are limited to the basic obligations of loyalty, good faith in the discharge of its mandate, providing full appropriate disclosure, and acting in the best interest of the

\footnotetext{
${ }^{28}$ Wewaykum Indian Band v. Canada [2002] S.C.R. (S.C.C.) at para. 83.

${ }^{29}$ Ibid. at paras. 86-104.
} 
beneficiaries. However, once a reserve has been created, the Crown's fiduciary duties expand to include the protection and preservation of the Indian band's interest from exploitation.

D. THE RIGHT TO AN ANCESTRAL TERRITORY (ABORIGINAL TITLE)

Aboriginal peoples have the right to the exclusive possession and use of lands occupied at the time of sovereignty. Aboriginal title exists as a burden on the Crown's underlying title and may not be transferred to third parties but only ceded to the Crown. ${ }^{30}$ As seen earlier, aboriginal title has a uniform legal character, which does not vary from group to group according to their customs. At the same time, aboriginal title provides a framework for the internal operation of the distinctive land laws of each aboriginal group and so allows for quite varied regimes of property rights and interests. ${ }^{31}$

Aboriginal title is similar in this respect to the title held by the provinces to lands within their boundaries under section 109 of the Constitution Act, 1867. In principle, the provincial title is a uniform one and gives provinces the same range of rights to their lands and resources, subject to any specific constitutional provisions. However, land laws obviously vary from province to province and generate distinctive regimes of property rights and interests. The property system of Quebec is very different from that of Manitoba.

\footnotetext{
${ }^{30}$ Delgamuukw v. British Columbia [1997] 3 S.C.R. 1010 (S.C.C.).

${ }^{31}$ See Brian Slattery, "The Metamorphosis of Aboriginal Title" (2006) 85 Can. Bar Rev. (forthcoming) and references in footnote 13, above.
} 


\section{E. THE RIGHT OF CULTURAL INTEGRITY}

As seen earlier, in Van der Peet the Supreme Court recognizes that aboriginal peoples have the right to maintain the central and significant features of their historical cultures. The generic right of cultural integrity gives birth to a host of specific rights that differ from group to group in accordance with their distinctive practices, customs and traditions, such as the right to hunt, the right to fish, the right to harvest certain natural resources, the right to practice a certain religion, the right to speak a certain language, and so on. Despite such differences, these specific rights fall into a number of broad classes, which relate to such subjects as livelihood, religion, language, and art. These classes constitute generic cultural rights of intermediate generality.

For example, the right to practice a traditional religion arguably qualifies as an intermediate cultural right because spirituality is normally a central and significant feature of aboriginal societies. Viewed in the abstract, this right has a uniform scope, which does not vary from one aboriginal people to another. However, the particular activities protected by the right differ from group to group, depending on the distinctive religious practices and beliefs of the group. In effect, then, the generic right of cultural integrity harbours an intermediate right to practice a traditional religion, which in turn shelters a plethora of specific religious rights vested in particular aboriginal groups.

Consider another example. Aboriginal groups arguably have the constitutional right to use their ancestral languages and to engage in the activities needed to maintain and perpetuate these languages, such as teaching these languages at school. The language of a group is normally an integral feature of its ancestral culture and an important means by which the culture is manifested, nurtured and transmitted. So the right to speak an aboriginal language has a strong claim to qualify as a cultural right of intermediate generality. According to this approach, the 
abstract dimensions of this right are identical in all aboriginal groups where the right occurs, however it gives rise to specific rights to speak and transmit particular aboriginal languages.

Perhaps the most important intermediate right is what we may call the right of livelihood. A fundamental principle informing the Crown's acquisition of sovereignty was that an aboriginal people could continue to gain its living in its accustomed manner. Justice McLachlin identified this right in her dissenting opinion in the Van der Peet case. ${ }^{32}$ Citing the terms of treaties and the Royal Proclamation of $1763,{ }^{33}$ she observed:

These arrangements bear testimony to the acceptance by the colonizers of the principle that the aboriginal peoples who occupied what is now Canada were regarded as possessing the aboriginal right to live off their lands and the resources found in their forests and streams to the extent they had traditionally done so. The fundamental understanding-the Grundnorm of settlement in Canada-was that the aboriginal people could only be deprived of the sustenance they traditionally drew from the land and adjacent waters by solemn treaty with the Crown, on terms that would ensure to them and to their successors a replacement for the livelihood that their lands, forests and streams had since ancestral times provided them. ${ }^{34}$

\footnotetext{
${ }^{32}$ R. v. Van der Peet [1996] 2 S.C.R. 507 (S.C.C.) at paras. 270-72.

${ }^{33}$ Royal Proclamation of 7 October 1763. The most accurate printed text is found in Clarence S. Brigham, ed., British Royal Proclamations Relating to America (Worcester, Mass.: American Antiquarian Society, 1911), 212.

${ }^{34}$ R. v. Van der Peet [1996] 2 S.C.R. 507 (S.C.C.) at para. 272.
} 
This viewpoint later attracted the Supreme Court's support in the Marshall case. ${ }^{35}$ In the course of interpreting a Mi'kmaq treaty concluded in 1760, Justice Binnie appealed to a fundamental precept of British imperial practice in North America, which held that when an aboriginal people passed under Crown sovereignty it was entitled to continue to sustain itself in the manner it had done previously. As Justice Binnie noted dryly, this principle was not wholly disinterested:

Peace was bound up with the ability of the Mi'kmaq people to sustain themselves economically. Starvation breeds discontent. The British certainly did not want the $\mathrm{Mi}^{\prime} \mathrm{kmaq}$ to become an unnecessary drain on the public purse of the colony of Nova Scotia or of the Imperial purse in London, as the trial judge found. To avoid such a result, it became necessary to protect the traditional $\mathrm{Mi}^{\prime} \mathrm{kmaq}$ economy, including hunting, gathering and fishing. ${ }^{36}$

The right of livelihood attracted detailed discussion in the recent Sappier case, ${ }^{37}$ where Justice Bastarache held that the weight of authority supports the view that section 35 protects the means by which an aboriginal society traditionally sustained itself. He went on to explain that the doctrine of aboriginal rights arises from the simple fact of prior occupation of the lands now forming Canada. So the Court's focus should be on the nature of this prior occupation. This involves an inquiry into the traditional way of life of a particular aboriginal community, including their means of survival.

\footnotetext{
${ }^{35}$ R. v. Marshall [1999] 3 S.C.R. 456 (S.C.C.).

${ }^{36}$ Ibid. at para. 25. See also: Mikisew Cree First Nation v. Canada (Minister of Canadian Heritage) [2005] 3 S.C.R. 388 (S.C.C.) at para. 26.

${ }^{37}$ R. v. Sappier; R. v. Gray 2006 SCC 54 (S.C.C.) esp. at paras. 37-40, 45.
} 
In summary, the right of cultural integrity forms a pyramid with three levels. At the top is the abstract right itself, which takes the same general form in all aboriginal groups. Beneath this lies a tier of intermediate generic rights which relate to distinct subject-matters such as livelihood, religion, language and art. At the bottom rests a broad range of specific rights that differ from group to group in accordance with their particular cultural characteristics.

\section{F. THE RIGHT OF SELF-GOVERNMENT}

Aboriginal peoples have the right to govern themselves within a federal constitutional framework characterized by a division of powers among various orders of government. ${ }^{38}$ This right finds its source in the British Crown's recognition that it could not secure the amity of the indigenous nations over which it claimed sovereignty without acknowledging their right to manage their own internal affairs. As Justice Lamer noted in the Sioui case, ${ }^{39}$ the Crown treated Indian nations with generosity and respect, out of the fear that the safety and development of British colonies would otherwise be compromised:

The British Crown recognized that the Indians had certain ownership rights over their land, it sought to establish trade with them which would rise above the level of exploitation and give them a fair return. It also allowed them autonomy in their internal affairs, intervening in this area as little as possible.

\footnotetext{
${ }^{38}$ Canada, Report of the Royal Commission on Aboriginal Peoples (Ottawa: Canada Communication Group, 1996); Campbell v. British Columbia (Attorney General) [2000] 4 C.N.L.R. 1 (B.C.S.C.); Brian Slattery, "First Nations and the Constitution: A Question of Trust" (1992) 71 Can. Bar Rev. 261 at $278-87$.

${ }^{39}$ R. v. Sioui [1990] 1 S.C.R. 1025 (S.C.C.) at 1054-55, emphasis added.
} 
It is submitted that the right of self-government is a generic right, which recognizes a uniform set of governmental powers held by aboriginal peoples as a distinct order of government within the Canadian federal system. At the same time, it allows aboriginal groups to establish and maintain their own constitutions, which take a variety of forms. There are close parallels here to the provinces, which possess a set of generic governmental powers under s. 92 of the Constitution Act, 1867, but also are entitled to maintain distinctive provincial constitutions.

It could be argued that the aboriginal right of self-government is not a generic right but a collection of specific rights, each of which has to be proven separately under the Van der Peet test. ${ }^{40}$ In the Pamajewon case, ${ }^{41}$ the Supreme Court viewed the question through the lens of Van der Peet and held that the right of self-government would have to be proven as an element of specific practices, customs and traditions integral to the particular aboriginal society in question. According to this approach, the right of self-government would be a collage of specific rights to govern particular activities rather than a generic right to deal with a range of abstract subject-matters. However, the Pamajewon case was decided prior to the Court's decision in Delgamuukw, which expanded the horizons of aboriginal rights and recognized the category of generic rights.

In the light of Delgamuukw, it seems more sensible to treat the right of self-government as a generic aboriginal right rather than a bundle of specific rights. On this view, the right of selfgovernment is governed by uniform principles laid down by

\footnotetext{
${ }^{40}$ The following discussion draws on Brian Slattery, "Making Sense of Aboriginal and Treaty Rights" (2000) 79 Can. Bar Rev. 196 at 213-14.

${ }^{41}$ R. v. Pamajewon [1996] 2 S.C.R. 821 (S.C.C.), at 832-33.
} 
Canadian common law. The basic scope of the right does not vary from group to group; however its application to a particular group differs depending on the circumstances. This is the approach taken in the Report of the Royal Commission on Aboriginal Peoples, which the Supreme Court cites in its brief comments on self-government in the Delgamuukw case. ${ }^{42}$

Nevertheless, certain other observations made in Delgamuukw might be considered adverse to this approach. In declining to be drawn into an analysis of self-government, the Court reiterates its holding in Pamajewon that rights to self-government cannot be framed in "excessively general terms" and notes that the aboriginal parties to the case had advanced the right to selfgovernment "in very broad terms, and therefore in a manner not cognizable under s. 35(1). ${ }^{\prime 43}$ It is submitted that these remarks should be understood simply as a warning against overambitious litigation, which attempts to induce the courts to settle very difficult questions in a vacuum, without an appropriate factual or doctrinal context. ${ }^{44}$

${ }^{42}$ Delgamuukw v. British Columbia [1997] 3 S.C.R. 1010 (S.C.C.), at 1115; see Canada, Report of the Royal Commission on Aboriginal Peoples (Ottawa: Canada Communication Group, 1996), Vol. 2, Part 1, esp. at 163-280. On the right of self-government, see Patrick Macklem, "First Nations SelfGovernment and the Borders of the Canadian Legal Imagination" (1991) 36 McGill L.J. 382; Brian Slattery, "First Nations and the Constitution: A Question of Trust" (1992) 71 Can. Bar Rev. 261 at 278-87; Patrick Macklem, "Distributing Sovereignty: Indian Nations and Equality of Peoples" (1993) 45 Stanf. L. Rev. 1311.

${ }^{43}$ Delgamuukw v. British Columbia [1997] 3 S.C.R. 1010 (S.C.C.), at 1114-15.

${ }^{44}$ As the Court states: "The broad nature of the claim [of self-government] at trial also led to a failure by the parties to address many of the difficult conceptual issues which surround the recognition of aboriginal selfgovernment. ... We received little in the way of submissions that would help us to grapple with these difficult and central issues. Without assistance from 


\section{THE RELATIONSHIP BETWEEN GENERIC AND SPECIFIC RIGHTS}

The link between generic and specific rights should now be clear. Specific rights are concrete instances of generic rights. So, for example, the generic right to honourable treatment by the Crown operates at a high level of abstraction and harbours a range of intermediate generic rights relating to different subjectmatters, such as the creation of Indian reserves or the protection of existing reserves. These intermediate rights, in turn, engender myriad specific fiduciary rights vesting in particular aboriginal groups, whose precise scope is determined by the concrete circumstances in which they arise. Similarly, the broad right of cultural integrity fosters a range of intermediate generic rights, which relate to such matters as livelihood, language and religion. These intermediate rights give birth to specific rights, whose character is shaped by the practices, customs and traditions of particular aboriginal groups.

The precise relationship between generic and specific rights varies depending on the generic right in question. Consider, for example, the generic right of self-government. As just seen, this arguably confers the same set of governmental powers on all aboriginal peoples in Canada. In this respect, the right of selfgovernment resembles the uniform package of governmental powers vested in the provinces. However, this abstract homogeneity does not mean that aboriginal peoples possess the same internal constitutions and governmental structures or that they exercise their governmental powers up to their full theoretical limits. An important component of the aboriginal right of self-government is the power of an aboriginal group to

the parties, it would be imprudent for the Court to step into the breach."; ibid., at 1115 . 
establish and amend its own constitution within the overarching framework of the Canadian Constitution. This power parallels the power of a province to amend its own constitution under section 45 of the Constitution Act, 1982. So, it appears that the generic right of self-government, in allowing for the creation of a variety of governmental structures, engenders a range of specific governmental powers and rights, as detailed in the particular constitutions of aboriginal groups.

However, not all generic rights blossom into specific rights. For example, the generic right to conclude treaties empowers aboriginal groups to enter into binding agreements with the Crown. As such, the right gives rise to a wide array of treaties, which differ in subject-matter and scope. While it is true that each such treaty represents the concrete application of the abstract generic right, it seems an excess of legal logic to say that each treaty therefore represents a "specific aboriginal right". Similarly, the generic right to an autonomous legal system harbours a host of distinct legal systems enjoyed by particular aboriginal groups. Although each such system is a concrete manifestation of the overarching generic right, it is arguably artificial to treat it as a specific right.

While not all generic rights give birth to specific rights, all specific rights are the offspring of generic rights. In other words, there are no "orphan" specific rights. The reason is that generic rights provide the basic rules governing the recognition and scope of specific rights. So an aboriginal group cannot possess a specific right unless it is rooted in a generic right; by the same token, the scope of a specific right cannot exceed the basic dimensions of the generic right that engenders it.

\section{THE UNIVERSALITY OF GENERIC RIGHTS}

Generic rights are not only uniform in character, they are also universal in distribution. They make up a set of fundamental rights presumptively held by all aboriginal groups in Canada. 
There is no need to prove in each case that a group has the right to conclude treaties with the Crown, to enjoy a customary legal system, to benefit from the honour of the Crown, to occupy its ancestral territory, to maintain the central attributes of its culture, or to govern itself under the Crown's protection. It is presumed that every aboriginal group in Canada has these fundamental rights, in the absence of valid legislation or treaty stipulations to the contrary. This situation is hardly surprising, given the uniform application of the doctrine of aboriginal rights across the country as a matter of Canadian common law. This doctrine applies to all the territories currently forming part of Canada, regardless of the precise manner in which the Crown acquired them or their original status as French or English colonies. ${ }^{45}$

The generic rights held by aboriginal peoples resembles the set of constitutional rights vested in the provinces under the general provisions of the Constitution Act, 1867. Just as every province presumptively enjoys the same array of governmental powers, regardless of its size, population, wealth, resources or historical circumstances, so also every aboriginal group, large or small, presumptively enjoys the same range of generic aboriginal rights.

However this conclusion could be disputed. For example, it could be argued that the generic right of aboriginal title is not a universal right. According to this viewpoint, certain aboriginal peoples did not have sufficiently stable connections with a definite territory to hold aboriginal title, although they may possess specific rights of hunting, fishing and gathering. Certain musings of the Supreme Court seem to entertain this

\footnotetext{
${ }^{45}$ See R. v. Côté [1996] 3 S.C.R. 139 (S.C.C.) at paras. 42-54; R. v. Adams [1996] 3 S.C.R. 101 (S.C.C.) at paras. 31-33; Brian Slattery, "Understanding Aboriginal Rights" (1987) 66 Can. Bar Rev. 727 at 736-41.
} 
possibility. ${ }^{46}$ However, the better view is that every aboriginal group presumptively holds aboriginal title to an ancestral territory, and that very strong evidence would be needed to overturn this presumption.

\section{THE INCEPTION OF ABORIGINAL RIGHTS}

As a matter of Canadian law, aboriginal rights came into existence when the Crown gained sovereignty over an aboriginal people-what we will call the "time of sovereignty". Before that time, the relations between an aboriginal people and the Crown were governed by international law and the terms of any treaties. Although aboriginal peoples clearly held rights in international law prior to the time of sovereignty (and continue to hold certain international rights today), it was only when the Crown gained sovereignty that aboriginal rights as such arose in Canadian law. ${ }^{47}$ So, it seems natural to think that the relevant historical date for establishing the existence of aboriginal rights is the time of sovereignty. However, the matter is not so straightforward. We have to distinguish between generic and specific rights.

\footnotetext{
${ }^{46}$ See R. v. Adams [1996] 3 S.C.R. 101 (S.C.C.) at paras. 27-28; R. v. Marshall/R. v. Bernard [2005] 2 S.C.R. 220 (S.C.C.) at paras. 58-59, 66. For discussion, see B. J. Burke, "Left Out in the Cold: The Problem with Aboriginal Title Under Section 35(1) of the Constitution Act, 1982 for Historically Nomadic Aboriginal Peoples" (2000) 38 Osgoode Hall L.J. 1; Brian Slattery, "The Metamorphosis of Aboriginal Title" (2006) 85 Can. Bar Rev. (forthcoming).

${ }^{47}$ For discussion of indigenous rights in international law, see S. James Anaya, Indigenous Peoples in International Law (New York: Oxford University Press, 1996).
} 


\section{A. GENERIC RIGHTS}

As seen earlier, when an aboriginal people passes under the Crown's sovereignty, it automatically gains a set of generic rights-the right of cultural integrity, the right to honourable treatment by the Crown, and so on. These rights come into existence at the time of sovereignty and possess a uniform character. Nevertheless, some generic rights have concrete aspects that change over time. For example, although the generic right to customary law arises at the time of sovereignty, the particular bodies of customary law protected by the right are not static but continue to evolve and adapt to keep pace with societal changes. It follows that the relevant date for determining the existence of a particular rule of customary law is not the date of sovereignty but the date of the activity or transaction whose legality is in question. So, for example, the validity of a purported customary adoption that occurred in 1960 has to be determined by the customary rules prevailing at that date. Of course, the applicable rules must have existed for an appreciable period of time for them to gain the status of customary law. However, there is no need to show they existed at the time of sovereignty.

Aboriginal title provides a different example. As seen earlier, when an aboriginal people passes under Crown sovereignty, it automatically gains title to its ancestral territories in Canadian law. So, prima facie, the boundaries of an aboriginal territory are ascertained by reference to the situation at the time of sovereignty. ${ }^{48}$ However, this general rule is subject to two qualifications, which we can discuss only briefly. The first relates to the Royal Proclamation of 1763, and the second to historical migrations.

${ }^{48}$ Delgamuukw v. British Columbia [1997] 3 S.C.R. 1010 (S.C.C.) at paras. 143-45. 
The Royal Proclamation of 1763 recognizes the rights of all aboriginal peoples living under the Crown's protection to the lands in their possession. ${ }^{49}$ It accepts the pattern of indigenous occupation existing in 1763 as the basis for aboriginal land rights, regardless of patterns of occupation that prevailed in earlier eras. So the Proclamation seems to provide a common historical baseline for all aboriginal groups living under British protection in 1763. However, there is good reason to think that, as of that date, the British Crown claimed sovereignty over the entirety of the territories now making up Canada. ${ }^{50}$ So, the year 1763 arguably constitutes a uniform baseline for the entire country, from Newfoundland in the east to British Columbia in the west.

The second qualification relates to historical migrations. In the fluid conditions that prevailed in early periods of Canadian history, it was common for aboriginal groups to migrate to new areas due to warfare, environmental change, depletion of resources, internal conflict, economic opportunities, and similar factors. The onset of Crown sovereignty did not bring this

\footnotetext{
${ }^{49}$ The Proclamation's text is found in Clarence S. Brigham, ed., British Royal Proclamations Relating to America (Worcester, Mass.: American Antiquarian Society, 1911), 212. For detailed discussion, see Brian Slattery, The Land Rights of Indigenous Canadian Peoples, As Affected by the Crown's Acquisition of Their Territories (D.Phil. thesis, Oxford University, 1979; reprint, Saskatoon: University of Saskatchewan Native Law Centre, 1979) at 204-82; Brian Slattery, "The Hidden Constitution: Aboriginal Rights in Canada" (1984) 32 Am. J. Comp. L. 361 at 368-72; Brian Slattery, "The Legal Basis of Aboriginal Title", in Aboriginal Title in British Columbia: Delgamuukw v. The Queen, ed. F. Cassidy (Lantzville, B.C.: Oolichan Books, 1992) at 121-29.

${ }^{50}$ See Brian Slattery, The Land Rights of Indigenous Canadian Peoples, As Affected by the Crown's Acquisition of Their Territories (D.Phil. thesis, Oxford University, 1979; reprint, Saskatoon: University of Saskatchewan Native Law Centre, 1979) at 175-90.
} 
process to a sudden halt. Aboriginal groups continued to migrate in response to changes in their circumstances. With the establishment of effective British government and the creation of reserves, aboriginal mobility was gradually reduced, although in some areas it persisted into relatively recent times. When an aboriginal group migrated to a new area after the date of Crown sovereignty (or after the year 1763, whichever is later), it seems arguable that within a certain period-perhaps twenty to fifty years-it would gain aboriginal title to the new territory that it occupied while losing title to the territory it left behind. ${ }^{51}$

\section{B. SPECIFIC RIGHTS}

As we have seen, specific aboriginal rights arise under the auspices of their generic counterparts. While generic rights come into existence at the time of sovereignty, specific rights do not necessarily originate at that date. For example, the broad principle of the honour of the Crown takes force at the time of sovereignty, however specific fiduciary rights normally stem from events occurring well after that time, as when aboriginal lands are ceded to the Crown or a reserve is created. In such cases the relevant date for proving a specific fiduciary right is obviously the date of the event that triggered it, not the date of sovereignty.

A more difficult issue is posed by the right of cultural integrity. Like other generic rights, the abstract right comes into existence at the time of sovereignty, and the same holds true of the intermediate generic rights that shelter under its auspices. What, then, of the specific cultural rights that occupy the bottom tier in the pyramid? In principle these specific rights cannot date

${ }^{51}$ See Delgamuukw v. British Columbia [1997] 3 S.C.R. 1010 (S.C.C.) per La Forest J. at paras. 197-98; Brian Slattery, "Understanding Aboriginal Rights" (1987) 66 Can. Bar Rev. 727 at 741-44, 755-69. 
from a period earlier than the time of sovereignty, because as a matter of Canadian law (as distinct from indigenous law or international law) they do not exist prior to that date. So, presumably they must arise either at the time of sovereignty or at some later period, depending on the precise nature of the right in question.

However, here we must draw a distinction between the date that a specific cultural right comes into existence and the date by reference to which its concrete content is determined-for the two are not necessarily the same. Supposing that a specific cultural right originates at the time of sovereignty, at what date is its concrete content fixed? This question is bedevilled by a puzzling problem. It stems from the fact that aboriginal cultures (like all cultures) are not static but undergo significant changes over time. After Europeans arrived in North America, aboriginal societies responded in a dynamic fashion to new opportunities, circumstances and influences. ${ }^{52}$ Just as European cultures quickly adopted many products of American origin, such as tomatoes, corn and potatoes (to say nothing of tobacco), so also native American cultures swiftly absorbed many items of European origin, such as horses, metal artefacts and firearms. Trade in furs, skins and fish transformed the economies of aboriginal societies and helped sustain the economies of the settler colonies. Christianity also had a notable impact on many aboriginal societies, as did aboriginal conceptions of personal freedom and federalism on European political thought. While venereal syphilis (often thought to be of American origin) took its toll in European societies, European diseases such as smallpox decimated many aboriginal societies and caused important changes in lifestyle, political organization and

\footnotetext{
${ }^{52}$ For a good survey, see Colin G. Calloway, New Worlds for All: Indians, Europeans, and the Remaking of Early America (Baltimore, Md.: John Hopkins University Press, 1997).
} 
outlook. ${ }^{53}$ So the question arises, given the dynamic nature of aboriginal cultures and the fact that they underwent significant changes both before and after sovereignty, by reference to what time period should the concrete content of specific cultural rights be fixed?

It is submitted that the most workable answer to this question is as follows. The doctrine of aboriginal rights and the honour of the Crown assured an aboriginal society that it had the right to retain and develop the central features of its culture as these existed at the time of effective Crown control. This approach universalizes the benchmark date laid down for Metis peoples in the Powley case, ${ }^{54}$ where the Court held that section 35 protects the customs and traditions that were historically important features of Métis communities "prior to the time of effective European control". While the ruling is explicitly limited to Metis groups, we submit that it should apply to aboriginal groups across the board. It is hard to see why Indian and Inuit peoples, who often had close social and economic links with Metis groups, should have their aboriginal rights determined at a different date. Such a discrepancy leads only to bizarre and unjust results, whereby the Metis partners in a trading relationship would gain aboriginal rights denied to their Indian partners, simply due to a difference in benchmark dates.

Of course, aboriginal cultures could (and did) change dramatically after the time of effective Crown control. In principle, an aboriginal society was free to take its cultural and

\footnotetext{
${ }^{53}$ See Bruce G. Trigger \& William R. Swagerty, "Entertaining Strangers: North America in the Sixteenth Century", in The Cambridge History of the Native Peoples of the Americas, Vol. 1: North America, Part 1, ed. B. G. Trigger and W. E. Washburn (Cambridge: Cambridge University Press, 1996) at 363.

Syphilis was probably carried back to Europe as early as 1493 .

${ }^{54}$ R. v. Powley [2003] 2 S.C.R. 207 (S.C.C.) at para. 18.
} 
economic life in any direction it found congenial. However, the Crown's honour was only pledged to protect the central aspects of an aboriginal society as they existed at the time of effective control and later evolved to adapt to modern conditions. ${ }^{55}$ Beyond that point, the members of aboriginal societies enjoyed the same legal rights and liabilities at common law as other members of the larger society. ${ }^{56}$

The rationale for this approach is not hard to understand. When aboriginal peoples were confronted with encroaching Crown control, they were apprehensive that their lives would undergo swift and forced change in unwelcome and harmful ways. They required assurance that they could continue in their current modes of life and adapt their societies at the pace and in the ways they considered desirable. The honour of the Crown was committed to providing this assurance, both as a matter of basic justice and also because it was necessary to maintain the friendship of aboriginal peoples, which was crucial to the peace and security of the colonies. So, in light of this rationale, it is submitted that the benchmark date for specific cultural rights is the period at which the Crown gained effective control over a particular aboriginal group.

However, in Van der Peet, ${ }^{57}$ the Supreme Court took a different approach. It held that the date for fixing the content of specific cultural rights is the time of European contact rather than effective control. The Court apparently considered that the right of cultural integrity was designed to preserve the central aspects

\footnotetext{
${ }^{55}$ On the evolution of aboriginal rights, see esp. R. V. Sparrow [1990] 1 S.C.R. 1075 (S.C.C.) at p. 1093; R. v. Sappier; R. v. Gray 2006 SCC 54 (S.C.C.) at paras. $48-49$.

${ }^{56}$ However, the Indian Acts notoriously did not respect this basic principle.

${ }^{57}$ R. v. Van der Peet [1996] 2 S.C.R. 507 (S.C.C.).
} 
of an aboriginal culture as these existed in their "original" form, prior to changes arising from European influence. The Court seems to have thought that there existed ideal types of aboriginal societies, untouched by outside influences, in the misty period prior to European contact. However, this approach loses sight of the underlying rationale for the right of cultural integrity, which is rooted in the honour of the Crown. It also makes little historical sense. For example, when the Indian nations of New France fell under effective British rule after 1763 , it would have strange for the Crown to seek to win their amity by guaranteeing the basic features of their cultures as these existed as much as two hundred years previous, when French adventurers first sailed up the St. Lawrence River. An approach less apt to win the friendship of the Indian nations and ensure the future security of Quebec can hardly be imagined.

\section{CONCLUSION}

We have seen that aboriginal rights fall into two basic classes: generic rights and specific rights. Generic rights comprise a range of basic rights presumptively held by all aboriginal groups under Canadian common law. They include the right to conclude treaties, the right to customary law, the right to honourable treatment by the Crown, the right to an ancestral territory, the right of cultural integrity, and the right of selfgovernment. These abstract rights have a uniform character, which does not change from group to group. Specific rights, by contrast, arise under the auspices of generic rights and assume different forms in different aboriginal groups, depending on the particular circumstances of each group. Ranged between basic generic rights and specific rights are rights of intermediate generality, which relate to particular subject-matters. We suggest that this scheme provides a simple and practical way of understanding the otherwise bewildering array of aboriginal rights recognized in section 35(1) of the Constitution Act, 1982. 